\title{
FAMIly Violence CASES in Alberta: A SNAPShot
}

\author{
JENNIFER KOSHAN ${ }^{*}$
}

\section{INTRODUCTION}

In a one week period in August 2008, four decisions concerning family violence were posted on the Alberta Courts website, ${ }^{1}$ all written by Justice Donald Lee of the Alberta Court of Queen's Bench. Three of the four decisions ${ }^{2}$ arose under Alberta's Protection Against Family Violence Act, ${ }^{3}$ and the fourth dealt with a criminal matter. ${ }^{4}$ This comment will review the cases as a snapshot of family violence matters coming before the Alberta Courts at a particular moment in time. ${ }^{5}$ In order to situate these cases, I will describe the PAFVA and its implementation in practice, and consider the interaction between the civil, criminal, and child welfare responses to family violence in this province. My analysis will show that these four decisions do illustrate many of the trends in family violence and the legal responses to it in Alberta, and raise some of the same concerns that have been addressed in reports and academic literature on family violence.

\section{The Protection Against Family Violence ACt AND ITS APPLICATION}

The PAFVA, which was first enacted in 1999, allows family members to apply for emergency protection orders (EPOs) in cases of family violence. ${ }^{6}$ Family relationships covered by the PAFVA include those between current and former spouses, adult interdependent partners, others residing (or formerly residing) in intimate relationships, ${ }^{7}$ and generally, between those related to one another by blood, marriage, adoption, or adult interdependent relationships, ${ }^{8}$ and children in the care and custody of any of the above

*

Associate Professor, Faculty of Law, University of Calgary. Note that an earlier version of this comment was posted on ABlawg: The University of Calgary Faculty of Law Blog on Developments in Alberta Law, online: Ablawg <http://ablawg.ca/2008/09/22/family-violence-cases-in-alberta-a-snapshot>.

1 Online: Alberta Courts <http://www.albertacourts.ab.ca/>. The cases were decided between 7-14 August 2008.

M.E.B. v. C.W.M., 2008 ABQB 484, [2008] A.J. No. 886 (QL) [M.E.B.]; N.L.B. v. K.G.C., 2008 ABQB 485, [2008] A.J. No. 887 (QL) [N.L.B.]; K.F. v. A.F., 2008 ABQB 496, [2008] A.J. No. 905 (QL) [K.F.]. R.S.A. 2000, c. P-27 [PAFVA]. Similar legislation exists in several other provinces and territories. See Victims of Domestic Violence Act, S.S. 1994, c. V-6.02 (Saskatchewan); The Domestic Violence and Stalking Act, C.C.S.M. c. D93(Manitoba); Domestic Violence Intervention Act, S.N.S. 2001, c. 29 (Nova Scotia); Victims of Family Violence Act, R.S.P.E.I. 1988, c. V-3.2 (P.E.I.); Family Violence Prevention Act, R.S.Y. 2002, c. 84 (Yukon); Protection Against Family Violence Act, S.N.W.T. 2003, c. 24 (Northwest Territories); Family Violence Protection Act, S.N.L. 2005, c. F-3.1 (Newfoundland and Labrador); Family Abuse Intervention Act, S.Nu. 2006, c. 18 (Nunavut). Ontario's proposed legislation, the Domestic Violence Protection Act, S.O. 2000, c. 33, was never proclaimed.

R. v. M.S., 2008 ABQB 488, [2008] A.J. No. 908 (QL) [M.S.].

Statistics Canada undergoes a similar exercise each year when it gathers statistics on women's shelters in a one-day period as a snapshot of overall trends. See e.g. Andrea Taylor-Butts, "Canada's shelters for abused women, 2005/2006” (2007) 27:4 Juristat 1, online: Statistics Canada <http://www.statcan. gc.ca/pub/85-002-x/85-002-x2007004-eng.pdf>.

PAFVA, supra note 3, s. 2(1).

Ibid., s. 1(1)(d)(i).

Ibid., s. 1(1)(d)(iii). 
persons. ${ }^{9}$ Family violence is defined to include acts, omissions, and threats to cause injury or property damage that intimidate or harm family members, as well as physical confinement, sexual abuse, and stalking. ${ }^{10}$ EPOs typically restrain contact between the respondent and claimant, ${ }^{11}$ although other conditions can also be made, including orders for exclusive possession of the family home ${ }^{12}$ and prohibitions against attending at a place of work, school, or other place. ${ }^{13}$ Provincial court judges and justices of the peace are empowered to grant EPOs on an application without notice to the respondent, ${ }^{14}$ in person or by telephone. ${ }^{15}$ Where an EPO is granted, it must be served on the respondent before it takes effect ${ }^{16}$ and must be reviewed by a justice of the Court of Queen's Bench in a hearing held not later than nine working days after the granting of the order. ${ }^{17}$

In an evaluation of the PAFVA completed in 2005, University of Calgary researchers analyzed data collected from court files with respect to the use of the PAFVA from 2002 to $2004 .{ }^{18}$ Amongst the findings of this study were:

- $\quad$ Claimants under the PAFVA were predominantly female (92.1 percent) and respondents were primarily male (94.5 percent).

- The most frequent categories of relationship between claimant and respondent were "spouses (31.9\%); common-law partners (19.6\%); ex-common law partners (15.9\%) and ex-partners, either legally separated or divorced (12.1\%).”

- $\quad$ Of the intimate relationships with children associated with them, most applications (75.6 percent) requested that the order cover the children.

- The majority of files did not include information on the racial background of the claimant or respondent, but on files where this information was provided, "both claimants and respondents were mostly Caucasian (53.4\% and 57\% respectively).”

- $\quad$ There was only one case involving a same-sex partner relationship that was explicitly acknowledged.

Ibid., s. 1(1)(d)(iv).

Ibid., s. 1(1)(e).

Ibid., s. 2(3)(b).

Ibid., s. 2(3)(c).

Ibid., s. 2(3)(a).

Ibid., s. 2(1).

Protection Against Family Violence Regulation, Alta. Reg. 80/1999, s. 4(2).

PAFVA, supra note 3, ss. 5(1), 2(6).

Ibid., s. 2(6).

Leslie Tutty, Jennifer Koshan, Deborah Jesso \& Kendra Nixon, Alberta's Protection Against Family Violence Act: A Summative Evaluation: Final Report (Calgary: RESOLVE Alberta, 2005), online: Government of Alberta <http://www.child.gov.ab.ca/home/images/familyviolence/Summative Evaluation.pdf $>$ [PAFVA Evaluation Report]. A number of the report's recommendations were adopted in amendments to the PAFVA in 2006. See Protection Against Family Violence Amendment Act, 2006, S.A. 2006, c. 8. An earlier evaluation of the PAFVA was conducted in 2000: see Howard Research, Implementation and Impact of the Protection Against Family Violence Act: Final Report (Edmonton: Howard Research and Instructional Systems, 2000). 
- In a majority of files (85.7 percent), the respondent had not been charged criminally for the same matter(s) at the time of the EPO application.

- Almost all of the cases (90 percent), included evidence of previous incidents of violence before the circumstances that were the subject of the EPO application.

- "Of the 976 applications [for EPOs] heard by Justices of the Peace [or] Provincial Court Judges in Alberta from 2002 to June of 2004, the majority (82.7\%) were granted.”

- In the 781 cases where information was available about the review in the Court of Queen's Bench, 70.4 percent of EPOs were confirmed or confirmed with some changes. ${ }^{19}$

- $\quad$ The PAFVA is used most frequently in Edmonton, with 55.3 percent of applications occurring in that city, as compared with only 12.4 percent in Calgary. ${ }^{20}$

These patterns play out to different degrees in M.E.B., N.L.B., and K.F. All three cases involve allegations of violence between intimate partners, ${ }^{21}$ and in two of the three cases (N.L.B. and K.F.), there were children of the relationship. ${ }^{22}$ All three relationships were heterosexual, and two of the three involved male respondents and female claimants, with the third, K.F., involving a female respondent and male claimant. ${ }^{23}$ The racial background of the parties is not mentioned by Lee $\mathrm{J}$. in any of the PAFVA cases.

What is the significance of these demographic details? First, it is important to recognize the reality that although the PAFVA covers elder abuse, child abuse, and other categories of violence between family members, cases of violence between intimate partners are heard most frequently under the Act, with cases of male against female violence being most common. This pattern mirrors reporting rates for family violence to the police, where wife assault is reported much more frequently than other forms of family violence. ${ }^{24}$ While the

19 PAFVA Evaluation Report, ibid. at 2-3.

$20 \quad$ Ibid. at 43.

$21 \quad$ M.E.B., supra note 2 at para. 10; N.L.B., supra note 2 at para. 2; K.F., supra note 2 at paras. 3, 8, $10-11$.

22 N.L.B., ibid.; K.F., ibid. at para. 3. There may also have been children of the relationship in M.E.B., ibid., but Lee J.'s decision does not explicitly deal with this question.

$23 \quad$ M.E.B., ibid. at para. 4; N.L.B., ibid. at para. 6; K.F., ibid. at paras. 2-3.

24 The most recent Statistics Canada report on police-reported violence is Jodi-Anne Brzozowksi, ed., Family Violence in Canada: A Statistical Profile 2004 (Ottawa: Statistics Canada, 2004). It found that "Among all family violence victims, $62 \%$ were victims of violence at the hands of a spouse" and that, "[f]emales were much more likely than their male counterparts to be victims of spousal violence (85\% versus 15\%)" (at 5). In the following year's report, which is the most recent of Statistics Canada in this area, women from Alberta reported the highest rates of violence in the country (10 percent). See Kathy AuCoin, ed., Family Violence in Canada: A Statistical Profile 2005 (Ottawa: Statistics Canada, 2005) at 15. In addition to gender, risk factors associated with higher rates of family violence included age (with those under 25 at highest risk), the nature of the relationship (with those in common law relationships of less than three years duration at highest risk) (at 18), and Aboriginality (at 20). 
Alberta government deliberately sought to ensure that the PAFVA would be gender neutral, ${ }^{25}$ it is important that this does not mask the actual reality of family violence in this province. ${ }^{26}$ This is not to argue that the PAFVA should only apply to male violence against females. The allegations in the K.F. case, if true, confirm that intimate violence may also involve female perpetrators and male victims. ${ }^{27}$ Rather, my contention is that the gendered nature of intimate partner violence should be taken into account when the supports and services required to respond to such violence, whether through the application of the PAFVA or otherwise, are being considered.

Second, the absence of information about the racial and cultural background of the parties makes it very difficult to assess whether the PAFVA is being used by victims of violence who come from racialized communities. Unique considerations may make it more difficult for racialized victims of violence to seek protection under legislation like the PAFVA, including concerns about immigration status, fear of the authorities, and fear of ostracism within their own communities. ${ }^{28}$ There are also doubts about the extent to which legislation such as the PAFVA applies on First Nations reserves. ${ }^{29}$ These considerations led the researchers conducting the PAFVA evaluation to recommend that the application forms used under the $P A F V A$ be revised to provide space to include demographic information about the claimant and respondent, including their racial and cultural background. ${ }^{30}$

See e.g. Alberta Justice, Protection Against Family Violence Act: Consultation Report (Edmonton: Alberta Justice, 1998) at 9 , where the government stated that the PAFVA was designed "to ensure gender bias does not enter into the protection orders or the way the dispute is resolved."

For a recent critique of the de-gendering of family violence, see Jennifer Koshan \& Wanda Wiegers, "Theorizing Civil Domestic Violence Legislation in the Context of Restructuring: A Tale of Two Provinces” (2007) 19 C.J.W.L. 145. The Alberta Law Reform Institute acknowledged the gendered nature of domestic abuse in its report Domestic Abuse: Toward an Effective Legal Response: Report for Discussion No. 15 (Edmonton: Alberta Law Reform Institute, 1995) at 9-14, 56. See also Ruth M. Mann, "Men's Rights and Feminist Advocacy in Canadian Domestic Violence Policy Arenas: Contexts, Dynamics, and Outcomes of Antifeminist Backlash” (2008) 3 Feminist Criminology 44 at 67, where she argues that the Alberta government implicitly recognized the gendered dynamics of family violence in its report Alberta Roundtable on Family Violence and Bullying: Finding Solutions Together (Edmonton: Government of Alberta, 2004).

The facts of K.F. are contested and will be discussed below. For an analysis of research on husband abuse, see Leslie Maureen Tutty, Husband Abuse: An Overview of Research and Perspectives (Ottawa: Health Canada, 1999). See also Joanne C. Minaker \& Laureen Snider, "Husband Abuse: Equality with a Vengeance?” (2006) 48 Canadian Journal of Criminology and Criminal Justice 753.

See e.g. Dianne L. Martin \& Janet E. Mosher, "Unkept Promises: Experiences of Immigrant Women with the Neo-Criminalization of Wife Abuse" (1995) 8 C.J.W.L. 3 at 26-31; Colleen Sheppard, "Women as Wives: Immigration Law and Domestic Violence” (2000) 26 Queen’s L.J. 1; Jennifer Koshan, "Sounds of Silence: The Public/Private Dichotomy, Violence, and Aboriginal Women" in Susan B. Boyd, ed., Challenging the Public/Private Divide: Feminism, Law, and Public Policy (Toronto: University of Toronto Press, 1997) 87 at 96-99. While these articles dealt largely with victims' reticence in the criminal context, the same concerns may be at play in the civil context. See Koshan \& Wiegers, supra note 26 at $170-71$.

$29 \quad$ For an analysis of this issue see Karen Busby, Jennifer Koshan \& Wanda Wiegers, "Civil Domestic Violence Legislation in the Prairie Provinces: A Comparative Legal Analysis” in Jane Ursel, Leslie M. Tutty \& Janice leMaistre, eds., What's Law Got To Do With It?: The Law, Specialized Courts and Domestic Violence in Canada (Toronto: Cormorant Books, 2008) 197 at 217-19. The authors conclude that the provisions of provincial domestic violence legislation dealing with exclusive possession of the family home are likely inapplicable on First Nations reserves, and while no-contact provisions are constitutionally sound, they may not be enforced by police because of concerns over jurisdiction. 
As noted above, the PAFVA Evaluation Report also quantified the number of files where criminal charges were laid for the incident(s) that were the subject of the PAFVA application. This was thought to be an important factor in assessing the interaction between the civil approach to family violence and the criminal approach. The government's intent in passing the PAFVA was not to replace the criminal justice response to violence, but to supplement it with remedies that would be more accessible and broader in scope. ${ }^{31}$ Interestingly, however, the PAFVA sometimes appears to be used as an alternative to the criminal law in practice, as illustrated by the cases in this sample. ${ }^{32}$ It is explicitly stated in two of the cases that no criminal charges had been laid in relation to the alleged abuse that formed the basis of the PAFVA application, ${ }^{33}$ and in the third case, there is no mention of criminal charges. ${ }^{34}$ This is so even though in one case, M.E.B., Lee J. noted that the claimant sought medical attention for her injuries and was "pursuing assault charges against the Respondent with the police.” ${ }^{35}$ In another case, N.L.B., there was sufficient evidence of family violence to confirm the EPO for a period of one year. ${ }^{36}$

These cases raise the question of whether the police are following the policy adopted in 1985, which is intended to leave the decision to lay domestic violence charges with the police, to be based upon whether they have reasonable and probable grounds to do so rather than the victims' wishes. ${ }^{37}$ Similar policies were introduced across Canada in the early $1980 \mathrm{~s},{ }^{38}$ although questions have been raised over the years about whether these policies are being consistently followed, or conversely, are being followed with a vengeance, resulting in dual charging of victims who use force to defend themselves. ${ }^{39}$ While incidents covered by the PAFVA may not always qualify for a criminal response, given the lower burden of proof under the PAFVA and its broader definition of violence as compared to the definition

Ibid. at 13-16. The PAFVA Evaluation Report reviews the history leading to the enactment of the PAFVA and the intent behind the legislation.

This finding is also consistent with the PAFVA Evaluation Report, ibid. at 47-48, which found that criminal charges were not laid in 85.7 percent of files. The most common reasons for not charging that were noted on court files were: police were not called (27.2 percent), no criminal offence occurred (25.3 percent), and insufficient evidence was available (13.5 percent). Investigation was still pending in 14.1 percent of files.

See M.E.B., supra note 2 at para. 11; K.F., supra note 2 at paras. 3, 11.

N.L.B., supra note 2.

M.E.B., supra note 2 at para. 11 . The claimant alleged a history of verbal and physical abuse at the hands of the respondent, but there are no further details about the incident that was the basis of the EPO (at para. 10).

N.L.B., supra note 2 at paras. 2-3. Again, this was a case where the claimant alleged a history of verbal and physical abuse as well as property damage, but no further details of the incident(s) forming the basis of the EPO are provided. It should be noted that the respondent did not give evidence at the review hearing where the EPO was confirmed.

The policies are described in the Domestic Violence Handbook for Police and Crown Prosecutors in Alberta (Edmonton: Alberta Justice, 2008), online: Government of Alberta <http://www.justice.gov. ab.ca/criminal_pros/downloads/2008/DV_Handbook_full_2008.pdf> [Domestic Violence Handbook] at $13-14$.

See Trevor Brown, "Charging and Prosecution Policies in Cases of Spousal Assault: A Synthesis of Research, Academic, and Judicial Responses,” online: Department of Justice < http://www.justice.gc.ca/ eng/pi/rs/rep-rap/2001/rr01_5rr01-5.pdf> at iii.

See e.g. Laureen Snider, “Making Change in Neo-Liberal Times” in Gillian Balfour \& Elizabeth Comack, eds., Criminalizing Women: Gender and(In)Justice in Neo-Liberal Times (Halifax: Fernwood, 2006) 323 at 340 . 
of assault under the Criminal Code,${ }^{40}$ a case such as M.E.B. does raise concerns about how the police approach relatively serious cases of intimate violence.

It is also interesting to note that two of the three PAFVA cases came before the Court of Queen's Bench due to allegations that no-contact orders had been breached ${ }^{41}$ There are no specific provisions under the PAFVA dealing with breaches of EPOs, but respondents may be charged under s. 127 of the Criminal Code, which creates an offence for disobeying a lawful court order without excuse. ${ }^{42}$

In M.E.B., a somewhat unusual situation arose in that the respondent attended at the claimant's residence before he had been served with the EPO, which had been granted earlier that day and provided for a no-contact order and exclusive possession of the residence to the claimant. The claimant called the police, but when they attended and served the EPO on the respondent, he continued to speak to the claimant and, as Lee J. put it, "to try to reconcile with her." ${ }^{\prime 3}$ The police eventually arrested and charged the respondent under s. 127 of the Criminal Code. ${ }^{44}$ Justice Lee found that there had been a breach of the EPO and confirmed that order for a period of one year. ${ }^{45}$

In contrast, in N.L.B., an EPO was granted on 10 July 2008 and confirmed by the Court of Queen's Bench on 23 July 2008 for a period of one year. ${ }^{46}$ The respondent was later arrested at the claimant's residence, which he was prohibited from attending, ${ }^{47}$ although it does not appear he was charged under s. 127 of the Criminal Code. At the breach hearing, Lee J. accepted the respondent's evidence that he had gone to the claimant's (and his former) residence because family members told him that she had abandoned their three young children there for several days. ${ }^{48}$ The respondent argued that this situation gave rise to a necessity defence..$^{49}$ There was also evidence that the claimant had contacted the respondent "demanding money and/or drugs," that she had both told him to "'forget' about" the nocontact order, and threatened to use it against him. ${ }^{50}$ In these circumstances, Lee J. found that the respondent had not breached the EPO, but he also advised the respondent to seek to vacate or amend the EPO to avoid further allegations of breaches in the future. ${ }^{51}$

In both M.E.B. and N.L.B., the Court assumed the jurisdiction to deal with the alleged breaches of the EPOs apart from any charges that were laid under s. 127 of the Criminal Code. It is questionable whether the legislature intended for breaches to be dealt with in this

R.S.C. 1985, c. C-46, s. 265(1): defines assault as the intentional application of force, or the threat of such application, without the victim's consent.

M.E.B., supra note 2 at para. 1; N.L.B., supra note 2 at para. 1.

Supra note 40, s. 127.

M.E.B., supra note 2 at para. 4.

Ibid. at paras. 5-6. Justice Lee noted that the s. 127 charge was proceeding concurrently in Provincial Court.

Ibid. at para. 15.

N.L.B., supra note 2 at paras. 2-3.

Ibid. at para. 5 .

Ibid. at paras. 6, 20.

Ibid. at para. 15.

Ibid. at paras. 9, 14, 16-17, 21.

Ibid. at paras. 22-23. 
way. In its review of legal responses to domestic violence, the Alberta Law Reform Institute recommended that proposed civil legislation remain silent on breaches so that they could be dealt with under s. $127,{ }^{52}$ which provides that "[e]very one who, without lawful excuse, disobeys a lawful order made by a court of justice ... is, unless a punishment or other mode

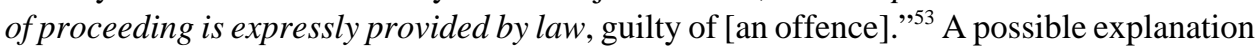
for the practice seen in M.E.B. and N.L.B. is provided in the PAFVA Evaluation Report, which contains excerpts of interviews conducted with a range of stakeholders, including the following comment from a police officer:

In Edmonton, there is a problem with breaches. Arrest on a breach, police had the option of using criminal code 127 . The breach was heard in criminal court. Judges began to not hear these, to say the breaches were 'frivolous,' and be heard in civil court instead. If a breach is a civil matter, history of breaches does not appear on a participant's record as it would if it heard in criminal court. This creates a lack of awareness for police, but also for judges in civil court who might not be aware of the criminal history. This might have been caused by orders without benefit of police assessment. ${ }^{54}$

It may be that it is more expeditious for breaches to be heard in this manner rather than in the context of a criminal trial. Further, victims may be more likely to report breaches, and police may be more willing to enforce them where the consequences are not as harsh as a criminal conviction. ${ }^{55}$ However, if breaches are to be dealt with under civil rather than criminal law, this should be considered by the legislature, and any decision in favour of this practice should be implemented through an amendment to the PAFVA. Civil domestic violence legislation in both Nova Scotia and Prince Edward Island contain provisions regarding breaches of protection orders and serve as potential models for Alberta, ${ }^{56}$ but this would likely mean that s. 127 of the Criminal Code could no longer be used for breaches given the wording of that section.

The third PAFVA case, K.F., was a review hearing to decide whether to confirm the EPO that had earlier been granted by the Provincial Court. ${ }^{57}$ This case is of interest because it involved a female respondent and male claimant. By affidavit, the claimant alleged a long history of emotional and physical abuse by the respondent. ${ }^{58}$ In opposition, the respondent's affidavit alleged that any violence she perpetrated was in defence of herself and the child of the relationship, and she characterized the claim against her as "vexatious and false." ${ }^{59}$ Both

Alberta Law Reform Institute, Protection Against Domestic Abuse: Report No. 74 (Edmonton: Alberta Law Reform Institute, 1997) at 162.

53 Supra note 40, s. 127 [emphasis added].

54 PAFVA Evaluation Report, supra note 18 at 74 . Similar concerns about the judicial treatment of breaches were expressed by other interviewees.

55 Koshan \& Wiegers, supra note 26 at 173, raise these concerns about the use of s. 127 and recommend further study of this issue.

56 See Domestic Violence Intervention Act, supra note 3, s. 18; Victims of Family Violence Act, supra note 3, s. 16.

K.F., supra note 2 at para. 1.

Ibid. at paras. 10-11.

Ibid. at para. 7. While no mention was made of it, s. 13 of the PAFVA, supra note 3, provides that "[n]o person shall, with malicious intent, make a frivolous or vexatious complaint under this Act.” The PAFVA Evaluation Report, supra note 18 at 94-95, recommended that this provision be removed from the $P A F V A$, as it may serve to deter valid complaints. This was not one of the recommendations adopted in the 2006 amendments to the PAFVA (supra note 18). 
the claimant and respondent accused each other of having a mental illness. ${ }^{60}$ Children's Services, which was involved in the matter in light of a pending child welfare application against the respondent, provided a letter expressing its opinion that she was "aggressive, threatening, and emotionally unstable," and supporting the respondent's argument that he was in need of protection under the PAFVA. ${ }^{61}$ Because the parties' affidavit evidence was conflicting, and there was no evidentiary basis put forward for the opinion of Children's Services, Lee J. ordered that the matter proceed to a full hearing with viva voce evidence. He further ordered that the existing EPO remain in place until the hearing. ${ }^{62}$

Although it is unclear how Children's Services became involved in the conflict between $K . F$., the case affords an opportunity to consider the interplay between child welfare concerns and family violence. Alberta's Child, Youth and Family Enhancement Act provides that "a child is in need of intervention if there are reasonable and probable grounds to believe that the survival, security or development of the child is endangered because ... the child has been emotionally injured" by his or her guardian. ${ }^{63}$ In turn, emotional injury is defined to include "exposure to domestic violence or severe domestic disharmony." ${ }^{\text {4 }}$

Concerns have been expressed about the possibility that such provisions might deter women from reporting abuse for fear of having their children apprehended. ${ }^{65}$ Critics also note that children can receive protection under legislation like the PAFVA by being included in the no-contact provisions of EPOs rather than being subjected to child welfare proceedings, an approach that focuses on the conduct of the perpetrator rather than the victim. ${ }^{66}$ However, if victims of violence are reluctant to turn to the authorities because of child welfare concerns, their access to the remedies under the PAFVA may be impeded. Alberta has attempted to alleviate this concern by including in the Child, Youth and Family Enhancement Act the proviso that "if a child has been exposed to domestic violence within the child's family, intervention services should be provided to the family in a manner that supports the abused family members and prevents the need to remove the child from the custody of an abused family member." ${ }^{, 67}$ Domestic violence is not defined in the Act, however, leaving much discretion to child welfare workers in the implementation of this provision, potentially leading to "inconsistent and inadequate responses."

K.F. also provides an opportunity to discuss the PAFVA provisions dealing with the review of EPOs. As noted earlier, all EPOs must be considered at a review hearing, to be held in the Court of Queen's Bench within nine working days of the order. ${ }^{69}$ Notice of the

$60 \quad$ K.F., ibid. at para. 6, 12.

Ibid. at paras. 14-15.

Ibid. at paras. 22-25.

R.S.A. 2000, c. C-12, s. 1(2)(f).

Ibid., s. 1(3)(a)(ii)(C).

Kendra L. Nixon et al., "Do good intentions beget good policy? A review of child protection policies to address intimate partner violence” (2007) 29 Children and Youth Services Review 1469 at 1470. This is a particular concern in the case of disadvantaged women. See Koshan \& Wiegers, supra note 26 at 171.

Nixon et al., ibid. at 1473.

Supra note 63, s. 2(f), cited in ibid. at 1479.

Nixon et al., ibid. at 1482.

PAFVA, supra note 3 , s. 2(6). 
hearing must be provided to the respondent in the EPO itself, ${ }^{70}$ and the review is to be based upon the evidence and documentation supporting the original EPO ${ }^{71}$ (including any notes taken at that time) ${ }^{72}$ as well as upon affidavit or sworn evidence. ${ }^{73}$ A reviewing justice is also empowered to order an oral hearing ${ }^{74}$ as Lee J. did in $K . F^{75}$

The review provisions in the PAFVA are generally more stringent than those in other civil domestic violence legislation in Canada. For example, in Manitoba, the onus is on the respondent to seek a review of an EPO made against them. ${ }^{76}$ In Saskatchewan, while the review is automatic, it is typically based on a reconsideration of the evidence available at the review hearing rather than new evidence. ${ }^{77}$ The $P A F V A$ 's requirement of affidavit evidence or sworn testimony makes the review procedure more onerous for claimants, but it seeks to ensure a full and fair hearing that likely immunizes the Act from a Charter challenge ${ }^{78}$ It is also noteworthy that even with these stricter evidentiary requirements, the vast majority (70.4 percent) of Queen's Bench reviews in Alberta result in the confirmation of emergency orders with or without some revisions. ${ }^{79}$ This in itself provides some validation of the EPO procedures.

Another matter of note is the fact that all three PAFVA cases in this sample were decided in Edmonton by Lee J. It is somewhat futile to speculate why this particular judge based in Edmonton rendered three decisions under the PAFVA in one week. Perhaps the PAFVA cases are being heard by a broader range of judges in a broader range of Alberta jurisdictions and are not being posted to the Alberta Courts website or other publicly accessible case law databases. In addition to the cases that are the subject of this comment, only five other cases considering the PAFVA are reported on such databases between 1 January 2008 and 31

Ibid., s. 3(1).

Ibid., s. 3(3).

Ibid., ss. 2(6), 3(2).

Ibid., ss. 2(6), 3(1)-3(3).

Ibid., s. 3(4)(b).

Supra note 2 at paras. 24-25. No decision is available to date on the outcome of this hearing.

The Domestic Violence Act, supra note 3, s. 11(1) provides that the respondent has 20 days following the service of the order in which to apply to have it set aside. Section 12(2) of the Act places the onus on the respondent to show why the order should be set aside. This provision was successfully challenged under the Canadian Charter of Rights and Freedoms, Part I of the Constitution Act 1982, Schedule B to the Canada Act 1982 (U.K.) 1982, c. 11 [Charter]. See infra note 78.

Victims of Domestic Violence Act, supra note 3, s. 5.

Charter, supra note 76. In Baril v. Obelnicki, 2007 MBCA 40, 279 D.L.R. (4th) 304 at para. 127, Manitoba's legislation was found to be consistent with s. 7 of the Charter, provided that the reverse onus clause in s. 12 of the Act was read down. According to the Court, "[a] respondent need only show, on a balance of probabilities, that there is an issue arising from the without notice hearing that entitles them to have the order set aside on the basis of absence of full disclosure or based on the weight of all the evidence adduced at both the without notice and review hearings" (at para. 5). The Court also found a violation of s. 2(b) of the Charter, but held that this violation was justified under s. 1 (at para. 64). In contrast, in A.L.G.C. v. Prince Edward Island (1998), 160 Nfld. \& P.E.I.R. 151 (P.E.I. S.C. (T.D.)), Prince Edward Island's legislation was found to violate s. 7 of the Charter in terms of procedural fairness (at paras. 36-45). For a discussion of these cases see Busby, Koshan \& Wiegers, supra note 29. There has been no constitutional challenge to Alberta's PAFVA to date.

PAFVA Evaluation Report, supra note 18 at 50-51. In approximately 25 percent of cases the EPO was revoked or vacated. 
August $2008 .^{80}$ If the number of applications under the PAFVA has remained consistent since the last evaluation of the legislation, this shows that very few cases are being reported at either the EPO or review stage of proceedings. It is to be hoped that this practice will be revisited, as these cases are a valuable source of information about the operation of the PAFVA. Because applications under the PAFVA are often made before a justice of the peace, and often by telecommunication, it is difficult to monitor the operation of the Act unless review decisions like those of Lee J. are posted. This is particularly important where the confirmation of the EPO is contested by the respondent.

The fact that all three PAFVA cases were from Edmonton might also suggest that the Act continues to be used more frequently in that city than elsewhere in the province. Police play a critical role in the usage of the PAFVA given that they are often first in contact with alleged victims of family violence. However, the PAFVA Evaluation Report found that in some communities, "the police prefer not to use the legislation." ${ }^{\prime 1}$ This problem was found to be particularly acute in rural and remote communities, resulting in access to justice issues given that the option of the victim applying through provincial court is more limited there. ${ }^{82}$ This led the authors of the report to recommend that the category of persons who are authorized to apply for EPOs under the PAFVA be broadened to include shelter and victims services workers. ${ }^{83}$ Training on the potential benefits of the PAFVA for police, and public education about the PAFVA were also recommended, ${ }^{84}$ and remain important ways of ensuring the fulsome use of the Act throughout Alberta.

\section{A Comparison BetweEn the PRotection Against FAMILY Violence ACt AND CRIMINAl CASES}

What about the criminal case in this sample? M.S. displays many of the same attributes of a "typical" family violence matter as the three PAFVA cases. It involves a male accused and female alleged victim in an intimate relationship with a young child. ${ }^{85}$ Unlike the cases under the PAFVA, however, ethnic background is explicitly mentioned in M.S. Justice Lee notes that the couple is from Sierra Leone, and that "the [c]omplainant believes that the [a]ccused tends towards domestic violence because of his background of cultural beliefs." ${ }^{86}$ The alleged assault was a serious one, involving a weapon (a shoe) and injuries requiring the attendance of emergency medical services at the scene (an eye that was completely swollen

The following Alberta cases considering the PAFVA in this period were found on review of the Alberta Courts website, supra note 1 and CanLII, online: CanLII <http://www.canlii.org>, the most publicly accessible legal databases: T.S. v. A.V.T., 2008 ABQB 185, 438 A.R. 113; M.K.D. v. A.J.I., 2008 ABQB 184, [2008] A.J. No. 368 (QL); M.K.D. v. A.J.I., 2008 ABQB 199, [2008] A.J. No. 369 (QL); Gauthier v. Descoteaux, 2008 ABQB 148, [2008] A.J. No. 278 (QL); L.R.B. v. C.A.M., 2008 ABPC 211, [2008] A.J. No. 795 (QL); B.J.B. v. K.T.L., 2008 ABPC 91, [2008] A.J. No. 364 (QL). Most of these cases did not directly consider relief under the PAFVA.

PAFVA Evaluation Report, supra note 18 at 59. This finding was based on interviews with police, child welfare workers, and justices of the peace.

Ibid.

Ibid. at 90. A similar recommendation was made by Koshan \& Wiegers, supra note 26 at 172.

PAFVA Evaluation Report, ibid. at 95-96.

M.S., supra note 4 at paras. 1, 13.

Ibid. at para. 10. 
shut, split and swollen lips, and a swollen, bruised left hand). ${ }^{87}$ The case came before the court as an application by the accused to waive the no-contact order made as a condition of his release on bail pending the trial of his criminal charge. ${ }^{88}$ The complainant gave evidence to support the accused's application, during which it was revealed that she was economically dependent on him, but felt that he would not reoffend, in part because he had taken an anger management class. ${ }^{89}$ The Crown opposed the application. ${ }^{90}$

The police charging policy mentioned above, and its companion prosecution policy were motivated by these kinds of cases in an effort to take the pressure off the alleged victim to decide whether to proceed with criminal charges. ${ }^{91}$ However, if the couple remains together between the time of the charges and the trial, pressure may be brought to bear on the complainant not to testify at trial, or to claim memory loss. Jurisdictions such as Calgary and Edmonton now have specialized domestic violence courts, the mandate of which is to provide support to all of the parties and resolve cases as expeditiously as possible to avoid situations like the one in M.S. ${ }^{92}$ Nevertheless, there will still be some delay between the time of the charges and the trial.

Justice Lee took many of these considerations into account in his decision in M.S., where he denied the application to remove the no-contact condition from the bail order. He noted that the complainant was only 21 years old, was financially dependent on the accused, isolated from her family, and that her actions were largely motivated out of fear that the accused would take their baby away from her. ${ }^{93}$ Justice Lee also expressed concern that the accused, "could persuade or influence the [c]omplainant in such a way that [she] will never testify fully at the trial of this matter."94 The accused was already permitted to have contact with the complainant in public and by telephone, and Lee J. held that this would have to be sufficient until trial. ${ }^{95}$ The fact that the accused had completed an anger management course was not seen as persuasive, with Lee J. finding that the course did "not materially reduce this risk and danger, particularly given the apparent additional cultural background issues here."96

It is helpful to see the issue of culture being explicitly acknowledged and discussed in a family violence case. However, it is unclear what evidence was before Lee J. other than the complainant's testimony about their culture. One would hope that assumptions were not made about the propensity for violence of persons from a particular ethnic or cultural background. Also of concern is the finding that the anger management course would not have made a material difference to the accused's risk of reoffending. If this conclusion was based

Ibid. at paras. 5, 8.

Ibid. at para. 1 .

Ibid. at paras. 14-15.

Ibid. at para. 3.

Domestic Violence Handbook, supra note 37 at 13-14; Brown, supra note 38 at iii. Brown discusses the debate about whether the policies have been effective at 1-2.

These courts operate at the provincial court level. Information about the specialized courts is available in the Domestic Violence Handbook, ibid. at 16-20. There were no family violence cases reported at the provincial court level in Alberta during the snapshot period considered in this comment.

M.S., supra note 4 at para. 24.

Ibid. at para. 27.

Ibid. at para. 28.

Ibid. at para. 25. 
on evidence, it points to the importance of ensuring that courses such as this are responsive to the needs of persons from varying cultural backgrounds. Many domestic violence perpetrators are ordered to take anger management courses as conditions of their sentences, suggesting that the judiciary puts a fair amount of faith into such courses. M.S. might simply be seen as an acknowledgment that this should not always be so, although to the extent this is tied to the cultural background of the accused and complainant, it does raise concerns.

\section{CONCLUSION}

Overall, it is noteworthy that this sample of cases reflects many of the trends in family violence matters noted in the PAFVA Evaluation Report as well as in the literature on legal responses to family violence. While the justice system has undergone significant reforms to provide more accessible procedures and remedies for family violence, concerns remain about the adequacy of these reforms. It is critical to recognize that legal responses to violence are only part of the solution to this social problem, and that access to shelters and other services, as well as other measures responding to social inequalities, are crucial. ${ }^{97}$ Within the legal realm, regular monitoring of family violence cases is important to obtaining a sense of how the civil and criminal justice approaches are working at a systemic level, and this can be facilitated if decisions such as Lee J.'s are written up and made available to the public on the Alberta Courts website, other legal databases, and published law reports. 